\title{
PROGNOSTIC FACTORS AFFECTING SURVIVAL IN ENDOMETRIAL CARCINOMA
}

\author{
Ates KARATEKE, Selcuk SELCUK, Mehmet Resit ASOGLU, Niyazi TUG, Cetin CAM, Ahmed NAMAZOV, Seda CAKIR \\ Department of Obstetrics and Gynecology, Zeynep Kamil Hostpital, Istanbul
}

\begin{abstract}
SUMMARY
Objective: Factors affecting survival in endometrial cancer patients were aimed to be investigated.

Material and methods: Survival, age, histopathologic diagnosis, stage, grade and lymphovascular space involvement of 172 endometrial cancer patients operated in Zeynep Kamil Hospital between 2001-2010 years were analyzed retrospectively. All patients were staged according to 1988 FIGO criteria. The effect of prognostic factors on 5 years survival rate and overall survival was evaluated.

Results and conclusion: Five years survival of 52 patients whom were operated at least 5 years ago was $76.9 \%$. There were significant effect of histological type, LVI and LN metastasis on five years survival rate. Furthermore; surgical staging, histological type, grade, LVI, LN metastasis and degree of myometrial invasion were found to be significant factors effected overall survival.
\end{abstract}

Key words: endometrial carcinoma, five years survey, overall survey

Journal of Turkish Society of Obstetrics and Gynecology, (J Turk Soc Obstet Gynecol), 2012; Vol: 9 Issue: 1 Pages: $42-6$

\section{ENDOMETRIUU KANSERİNDE SAĞKALIMI ETKİLEYEN PROGNOSTİK FAKTÖRLER}

\section{ÖZET}

Amaç: Bu çalışmada endometrium kanseri olgularında să̆ kalımı etkileyen faktörlerin incelenmesi amaçlandı. Gereç ve yöntemler: Zeynep Kamil Eğitim ve Araştırma Hastanesi Jinekolojik Onkoloji Kliniğinde 2001-2010 yılları arasında opere olmuş 172 endometrium kanseri olgusunun yaş, cerrahi evre, tümör histopatolojik tip, grade, myometrial invazyon derinliği, lenfovasküler alan tutulumu ve lenf nodu tutulumu ve sağ kalım verileri kaydedildi. Hastalar 1988 FIGO kriterlerine göre evrelendi. Prognostik faktörlerin 5 yıllık să̆ kalım oranları ve sağkalım süresi üzerindeki etkileri araştırıldl.

Bulgular ve sonuç: Operasyonun üzerinden en az beş yıl geçmiş 52 olgunun beş yıllık sağ kalım oranı \% 76.9 olarak hesaplandı. Histolojik tip, LVI ve LN metastazı 5 yıllık sağkalım oranları üzerine istatatiksel olarak anlamlı etkisi olan prognostic faktörler olarak bulundu. Cerrahi evre, histolojik tip, grade, LVI, LN metastazl ve myometrial invazyon derinliği sağkalım süresini anlamlı olarak etkileyen prognostic faktörler idi.

Anahtar kelimeler: endometrium kanseri, beş yıllık sağkalım, sağkalım

Türk Jinekoloji ve Obstetrik Derneği Dergisi, (J Turk Soc Obstet Gynecol), 2012; Cilt: 9 Sayl: 1 Sayfa: 42- 6

Address for Correspondence: Selçuk Selçuk. Zeynep Kamil Hastanesi, Üsküdür, İstanbul

Phone: + 90 (0505) 3580203

e-mail: md_sel@hotmail.com

Received: 06 April 2011, revised: 04 November 2011, accepted: 22 November 2011, online publication: 08 . December 2011 


\section{INTRODUCTION}

Endometrial carcinoma is the most common gynecological malignancy in developed but not in underdeveloped countries ${ }^{(1)}$. Incidence of endometrial carcinoma have been suggested to be increased by the higher rates of post-menopausal hormone replacement, increased life expectancy and the emergence of highly sensitive diagnostic modalities ${ }^{(2)}$. In this study, factors affecting survival in endometrial cancer patients were aimed to be investigated retrospectively.

\section{MATERIAL AND METHODS}

Totally 172 patients with the diagnosis of endometrial carcinoma operated in Zeynep Kamil Hospital, Gynecologic Oncology clinic between 2001 and 2010 were analyzed retrospectively. Four patients of whom all of the pathological examinations were not performed in this hospital were excluded from the study. All patients were staged according to 1988 FIGO criteria ${ }^{(3)}$. Pelvic and/or para-aortic lymph node dissection (LND) was performed in the presence of myometrial invasion depth of tumor $>1 / 2$, isthmus-cervix extension and extrauterine disease, tumor size larger than $2 \mathrm{~cm}$ and squamous,clear cell, serous tumor hystology. Paraaortic LND was perfomed on inferior and superior of the IMA on suitable patients acording to their obesity and comorbidity. Stage la-1b grade 1-2 patients did not receive radiotherapy post-operatively. Endometrioid type cases with higher stages/grade underwent post-operative external pelvic or extended radiotherapy or brachytherapy, (paclitaxel $175 \mathrm{mg} / \mathrm{m}^{2}+$ carboplatin, 4-6 times) and all patients with serous papillary or clear cell carcinomas received postoperative chemotherapy regardless of stage or grade of the disease. Survival, age, histopathologic diagnosis, stage, grade, lymphovascular space involvement (LVI), lymph node (LN) metastasis of the patients were recorded. Data were given as percent or mean \pm standard deviation (SD). Statistical analysis was performed Chi-square, Fisher's exact tests and Kaplan-Meier survival analysis. Degree of significance was set at $\mathrm{p}=0.05$.

\section{RESULTS}

Among 172 patients, demographic data of 168 patients of whom all of the pathological examinations were performed in our hospital were: age $=60.1 \pm 9.5$ years and parity $=3.01 \pm 2.3 .28$ patients underwent total abdominal hysterectomy and bilateral salpingo-oopherectomy (TAH + BSO), 75 patients underwent $\mathrm{TAH}+\mathrm{BSO}+$ pelvic lymph node dissection (LND), and both pelvic and paraaortic LND was performed in 69 patients. The mean number of pelvic and para-aortic lymph nodes was $16,14 \pm 11,4$ and 4,31 $\pm 3,4$ respectively.

Tumors of 144 patients were endometrioid and 24 were non-endometrioid type adenocarcinoma. Subtypes of the non-endometrioid adenocarcinoma were clear cell $(n=3)$, papillary serous $(n=12)$, mixed $(n=5)$, mucinous $(n=3)$ and undifferentiated $(\mathrm{n}=1)$ types. 86 patients were younger than 60 years and remaining 82 were at least 60 years of age. According to the 1988 FIGO criteria, 137 patients were stage I, 6 cases were stage II, 22 cases were stage III and 3 cases were stage IV. Grades of the disease were grade I in 64, grade II in 61 and grade III in 43 patients. Size of the tumor was smaller than $2 \mathrm{~cm}$ in 50 patients and at least $2 \mathrm{~cm}$ in 118 patients. In 101 patients, the tumor was confined to the inner $1 / 2$ of the myometrial wall where as in 67 patients it was beyond this level. LVI was positive in 61 patients and negative in 107 patients. Lymph node involvement was found in 18 patients among 144 patients to whom lymph node sampling was performed (Table I).

Table I: Five years survival rates of 52 patients with endometrial carcinoma.

\begin{tabular}{|c|c|c|c|c|}
\hline & & $\mathbf{n}$ & $\%$ & $\mathbf{p}$ \\
\hline \multirow[t]{2}{*}{ Age (years) } & $<60$ & 31 & 83.9 & \multirow{2}{*}{0.267} \\
\hline & $\geq 60$ & 21 & 66.7 & \\
\hline \multirow[t]{4}{*}{ FIGO stage } & I & 36 & 83.3 & \multirow{4}{*}{0.171} \\
\hline & II & 5 & 80.0 & \\
\hline & III & 8 & 62.5 & \\
\hline & IV & 3 & 33.3 & \\
\hline \multirow[t]{3}{*}{ Histological grade } & I & 15 & 93.3 & \multirow{3}{*}{0.096} \\
\hline & II & 22 & 77.3 & \\
\hline & III & 15 & 60.0 & \\
\hline \multicolumn{5}{|l|}{ Lymphovascular } \\
\hline involvement & No & 27 & 92.6 & \multirow{2}{*}{0.014} \\
\hline & Yes & 25 & 60.0 & \\
\hline \multicolumn{5}{|l|}{ Lymph node } \\
\hline metastasis & No & 43 & 83.7 & \multirow{2}{*}{0.035} \\
\hline & Yest & 9 & 44.4 & \\
\hline \multirow[t]{2}{*}{ Histological type } & Endometrioid & 44 & 86.4 & \multirow{2}{*}{$0.001 *$} \\
\hline & Non-endometrioid & 8 & 25.0 & \\
\hline \multicolumn{5}{|l|}{ Myometrial } \\
\hline \multirow[t]{2}{*}{ invasion } & $<1 / 2$ & 25 & 88.0 & \multirow{2}{*}{0.135} \\
\hline & $\geq 1 / 2$ & 27 & 66.7 & \\
\hline \multirow[t]{2}{*}{ Tumor size } & $<2 \mathrm{~cm}$ & 15 & 86.7 & \multirow{2}{*}{0.485} \\
\hline & $\geq 2 \mathrm{~cm}$ & 37 & 73.0 & \\
\hline
\end{tabular}




\section{Five years survival:}

Five years survival of 52 patients whom were operated at least 5 years ago was $76.9 \%$. Five years survival rates of 52 patients with endometrial carcinoma were given in Table I. Five years survival of patients younger than 60 years of age was $83.9 \%$ and that of patients at least 60 years was $66.7 \%$. No significant difference was found between these groups by means of five years survival $(\mathrm{p}=0.267)$.

Five years survival of the patients according to stage of the disease was: $83.3 \%$ in stage I, $80 \%$ in stage II, $62.5 \%$ in stage III and $33.3 \%$ in stage IV. No significant difference was found between stages $(p=0.171)$.

Endometrioid type adenocarcinoma patients had a five years survival rate of $86.4 \%$ where as this rate was $25 \%$ in non-Endometrioid type patients. Rate of five years survival differed significantly between patients with endometrioid and non-endometrioid types of endometrial carcinoma $(\mathrm{p}=0.001)$.

The five years survival rates of the grade I-III cases were $93.3 \%, 77.3 \%$ and $60 \%$, respectively. No significant difference was found between grade I-III groups $(\mathrm{p}=0.096)$.

Five years survival rates of patients with and without LVI were $60 \%$ and $92.6 \%$. There was statistically significant difference between two groups $(\mathrm{p}=0.014)$. Significant difference by means of five years survival was found between patients with lymph node involvement and those with no involvement $(44,4 \%$ and $83,7 \%$, respectively $\mathrm{p}=0.035$ ).

Five years survival rates were not differed between patients with tumors smaller than $2 \mathrm{~cm}$ and those with at least $2 \mathrm{~cm}(86,7 \%$ and $73 \%$ respectively, $\mathrm{p}=0.485)$ and between patients with tumor confined to inner $1 / 2$ of myometrium and those had beyond this level $(88 \%$ and $66.7 \%$, respectively, $\mathrm{p}=0.135$ ).

\section{Survival analysis:}

Kaplan-Meier survival analysis was performed in the evaluation of 106 patients who attended regular postoperative visits (Figures 1a-f). Survival of these patients was measured as $18-111$ months. Age $<60$ or $\geq 60$ years were not found as a significant factor effect survey in our study. However, surgical staging, histological type, grade, LVI, LN metastasis and degree of myometrial invasion were found to be significant factors for survival (Table II).
Table II: Overall survival analysis of 106 patients with endometrium carcinoma (Kaplan-Meier survival nalysis).

\begin{tabular}{ll}
\hline & $\mathbf{P}$ \\
\hline Age & 0.127 \\
Stage & 0.015 \\
Histological type & 0.000 \\
Grade & 0.040 \\
Lymphovascular involvement & 0.001 \\
Lymph node metastasis & 0.001 \\
Myometrial invasion & 0.017 \\
Tumor size & 0.296 \\
\hline
\end{tabular}

\section{DISCUSSION}

Endometrial cancer is the most commonly diagnosed gynecologic malignancy in the world ${ }^{(4,5)}$. The most of the patients were diagnosed with endometrium cancer limited to the uterus and overall 5-year survival rate of those patients was approximately $80 \%{ }^{(6)}$. Age of the patient, histological type, grade, LVI, depth of myometrial invasion and LN metastasis sites have been identified as predictors of clinical outcome(7,8). Assessment of the effect of prognostic factors on survey provides to perform optimum treatment. In present study, there were significant difference by means of histological type, LVI and LN metastasis according to the five years survival rate. Moreover; surgical staging, histological type, grade, LVI, LN metastasis and degree of myometrial invasion were found to be significant factors effected overall survival.

Endometrial carcinoma was classified as endo-metrioid and non-endometrioid type (serous papillary, clear cell, mucinous, undifferantied, mixed) ${ }^{(9)}$. Non-endometrioid type of endometrial carcinoma tends to have lower survival rates as compared to endometrioid type ${ }^{(10)}$. In this study, patients with non-endometrioid type tumor were lived shorter than those with endometrioid type.

Surgical stage is among the most important prognostic factors in endometrial carcinoma ${ }^{(2)}$. In a large study conducted by Abeler et al. five years survival rates were $83 \%$ in stage I, $75 \%$ in stage II $42 \%$ in stage III and $26 \%$ in stage IV patients ${ }^{(11)}$. In this study only 5 years survival rates calculated. These rates in patients with stage I-IV disease were $83.3 \%, 80 \%, 62.5 \%$ and $33.3 \%$, respectively. LN. metastasis, grade, myometrial invasion, adnexal involvement can be considered as factors affect surgical staging, consequently surgical staging become one of the most important prognostic factors.

Tumor grade is also known to affect survival ${ }^{(2)}$. In the literature, the association between grade and myometrial 
invasion, LN metastasis was known and higher histological grade decreases the survival rate. Five years survival rates of grade I-III endometrial carcinoma in the literature were $71-88 \%$ for grade I, $60-79 \%$ for grade II and $32-65 \%$ for grade III ${ }^{(12-15)}$. In the present study, five years survival rates were $93.3 \%$ for grade I, $77.3 \%$ for grade II and $60 \%$ for grade III, and these rates were consist with literature. There was no significant difference between grade and five years survival rates. The reason for these findings was suggested to be the relatively low number of the analysis. However the overall survival analyzes showed a statistically significant difference among grade I-III.

Myometrial invasion depth and lymph node involvement are also known to affect survival in endometrial carcinoma $^{(16-19)}$. In a large study carried out by Jones et al. five years survival rates of patients with or without deep myometrial invasion were found as $60 \%$ and $80 \%$, respectively ${ }^{(20)}$. In the present study, five years survival rates of such patients were calculated as $66.7 \%$ and $88 \%$, respectively but there was no statistical significance. Hence in overall survival analyze, myometrial invasion had a significant impact on survival.

The rate of LN metastasis increases with the advanced surgical staging, higher histological grade and deep myometrial invasion(9). The association of poor prognosis factors interprets the lower survival rate. The results of our study support these assumptions. We found a significant difference between five years survival rates of patients with and without lymph node metastasis. Furthermore, in the overall survival analysis lymph node involvement of the disease was found to affect survival significantly $(\mathrm{p}=0,001)$.

Figure 1: Kaplan-Meier survival analyses of all patients.

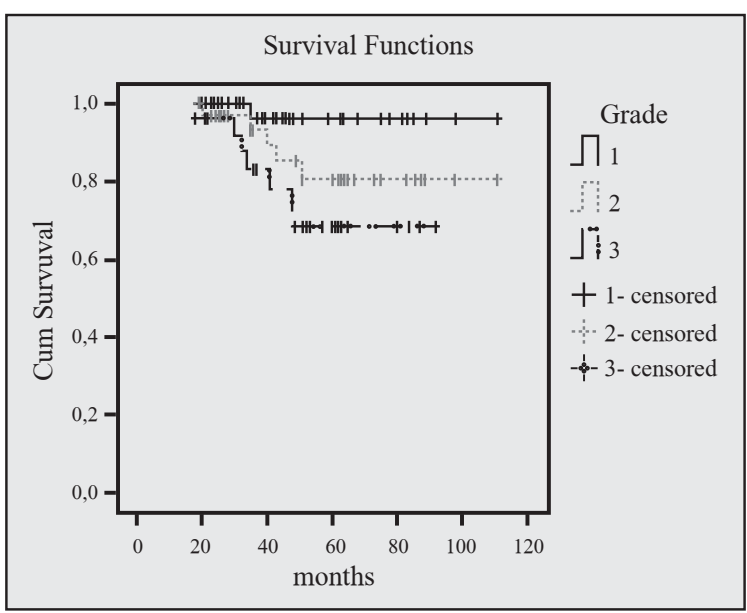

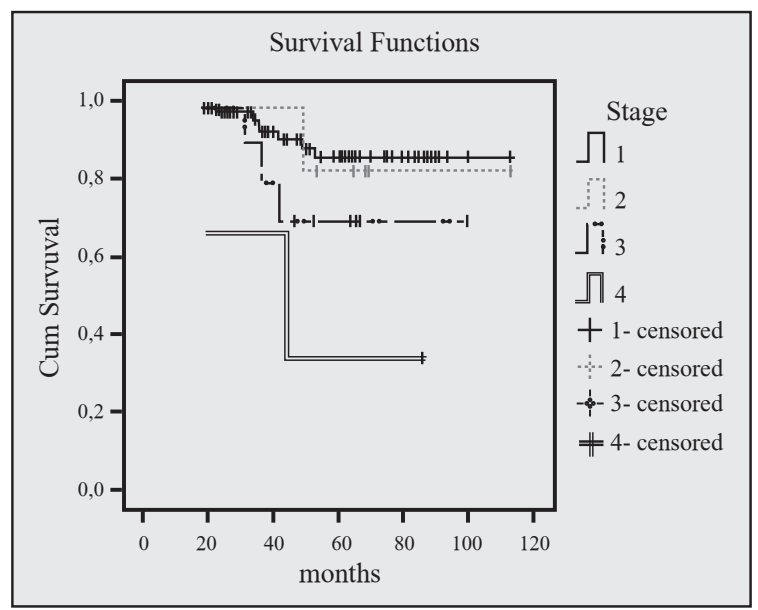
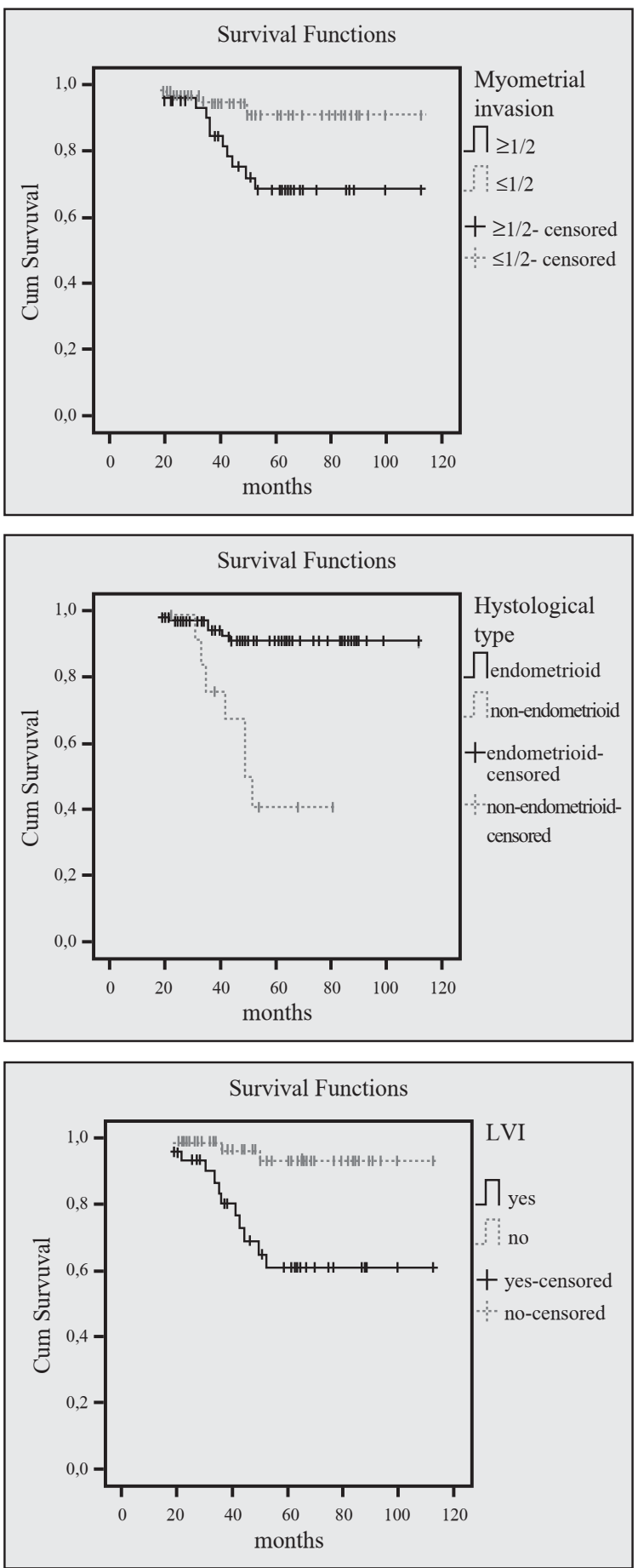


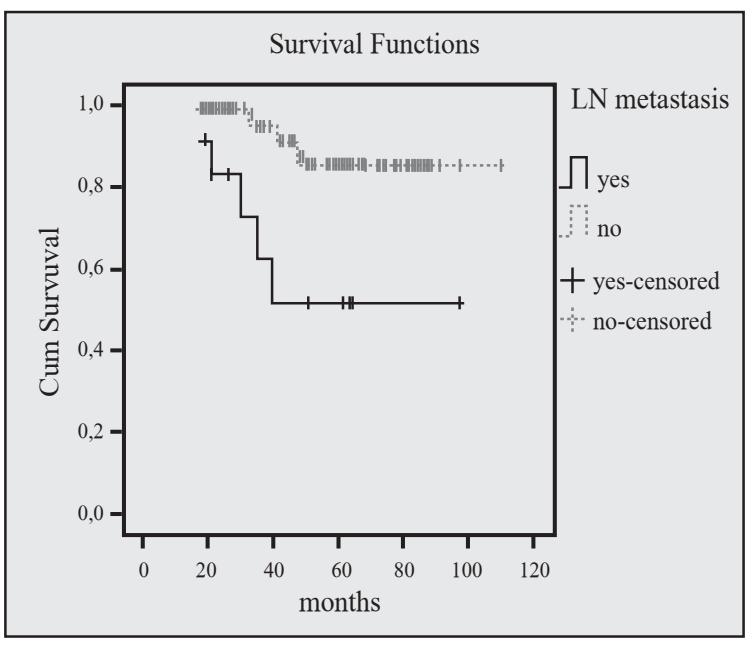

In conclusion, according to the results of this study:

1- The five years survival rate was $76.9 \%$ in the analyzed patients

2- Histological type, LVI and LN metastasis had a statistically significant affect on the five years survival rate.

3- Surgical staging, histological type, grade, LVI, LN metastasis and degree of myometrial invasion were found to be significant factors effected survival in the overall survival analyses.

\section{REFERENCES}

1. Jemal A, Siegel R, Ward E, Hao Y, Xu J, Murray T, et al Cancer statistics. CA Cancer J Clin. 2008; 58: 71- 96.

2. Kim JW, Kim SH, Kim YT, Kim DK. Clinicopathologic and biological parameters predicting the prognosis in endometrial cancer. Yonsei Med J. 2002; 43: 769- 78

3. FIGO (International Federation of Gynecology and Obstetrics) FIGO stages, 1988 revision. Gynecol Oncol. 1989; 35: 125- 7.

4. Jemal A, Murray T, Ward E, Samuels A, Tiwari RC, Ghafoor A, et al. Cancer statistics, 2005. CA Cancer J Clin. 2005; 55: 10- 30 .

5. Society CC. Canadian Cancer Statistics 2006; Toronto, Canada April 2006, ISSN 0835- 2976.

6. Creasman WT, Odicino F, Maisonneuve P, Beller U, Benedet JL, Heintz AP, et al. Carcinoma of the corpus uteri. J Epidemiol Biostat. 2001; 6: 47- 86.

7. Keskin N, Buyru F, Benginsu E, Sühaoğlu Y, Berkman S.
Factors infuencing the prognosis of endometrial carcinoma. T Klin J Gynecol Obst 1996, 6: 254- 8.

8. International Federation of Gynecology and Obstetrics. Announcements: FIGO stages-1988 revision. Gynecol Oncol. 1989; 35: 125- 7 .

9. Creasman WT, Morrow CP, Bundy BN, Homesley HD, Graham JE, Heller PB. Surgical pathologic spread patterns of endometrial cancer. Cancer. 1987; 60: 2035- 41.

10. Dunton CJ, Balsara G, McFarland M, Hernandez E. Uterine papillary serous carcinoma: a review. Obstet Gynecol Surv. 1991; 46: $97-102$.

11. Abeler VM, Kjørstad KE. Endometrial adenocarcinoma in Norway. A study of a total population. Cancer. 1991; 67: 3093- 103.

12. Wolfson AH, Sightler SE, Markoe AM, Schwade JG, Averette HE, Ganjei P, et al. The prognostic of surgical staging for carcinoma of the endometrium. Gynecol Oncol. 1992; 45: 142- 6 .

13. Christopherson WM, Connelly PJ, Alberhasky RC. Carcinoma of the endometrium. V. An analysis of prognosticators in patients with favorable subtypes and Stage I disease. Cancer. 1983; 51: $1705-9$

14. Creasman WT, Morrow CP, Bundy BN, Homesley HD, Graham JE, Heller PB. Surgical pathologic spread patterns of endometrial cancer. Cancer. 1987; 60: 2035- 41.

15. Pfleiderer A, Kleine W, Maier T, Schwörer D, Geyer H, Kaufmehl $\mathrm{K}$. Prognostic factors and endometrial carcinoma. Eur J Gynaecol Oncol. 1989; 10186- 91.

16. Morrow CP, Bundy BN, Kurman RJ, Creasman WT, Heller $\mathrm{P}$, Homesley HD, et al. Relationship between surgical-pathological risk factors and outcome in clinical stage I and II carcinoma of the endometrium:AGOG study. Gynecol Oncol. 1991; 40: 55- 60 .

17. Lee KR, Vacek PM, Belinson JL. Traditional and nontraditional histopathologic predictors of recurrence in uterine endometrioid adenocarcinoma. Gynecol Oncol. 1994; 54: 10- 8.

18. Marizale P, Atlante G, Pozzi M, Diotallevi F, Lacovelli A. 426 cases of stage I endometrial carcinoma: A clinico pathological analysis. Gynecol Oncol. 1989; 32: 278- 81.

19. Boronow RC, Morrow CP, Creasman WT, Disaia PJ, Silverberg SG, Miller A, et al. Surgical staging in endometrial cancer: clinical-pathologic findings of a prospective study. Obstet Gynecol. 1984; 63: 825- 32.

20. Jones HW. Treatment of adenocarcinoma of the endometrium. Obstet Gynecol Surv. 1975; 30: 147- 69. 